\title{
Growth Response of Rats Fed with a Diet Containing Nondialyzable Melanoidin ${ }^{\dagger}$
}

\author{
Masao Fujimaki, Seiichi Homma, Nobuhiko Arakawa \\ and Choten INAGAKI \\ Department of Food and Nutrition, Ochanomizu University, \\ Ohtsuka 2-1, Bunkyo-ku, Tokyo \\ Received July 20, 1978
}

\begin{abstract}
Nondialyzable ${ }^{18} \mathrm{~N}$-melanoidin was prepared from a model system of glucose and ${ }^{15} \mathrm{~N}$ glycine, and the growth response of rats fed with the dietary melanoidin was examined. Measurement of the excreted melanoidin by ${ }^{15} \mathrm{~N}$-balance revealed that $76 \%$ of the dietary melanoidin was excreted in the feces. Measurement of brown pigments in aqueous extract from the feces and in the urine by colorimetry indicated that $65 \%$ of the dietary melanoidin was excreted in the feces but none in the urine. It is speculated from the gel filtration chromatography of melanoidin that low molecular components of the dietary melanoidin were degraded into less or non-colorant materials through digestion and absorption in the intestines and that part of degraded melanoidin was retained by rats. Both low molecular components and reducing value of the fecal melanoidin were smaller than those of the original melanoidin.

Growth response, protein digestibility and lipid digestibility of the rats fed with the dietary melanoidin were not significantly different from those of the control.
\end{abstract}

It was previously reported by Fujimaki et al. ${ }^{1)}$ that melanoidin prepared from the model system showed antioxidant activity against unsaturated fatty acids. Melanoidin formed in the course of processing of food ${ }^{2 /}$ such as cookies has also been found a useful antioxidant. Therefore, it seems possible that application of melanoidin to food processing, both that formed in the course of food processing and that used as a food additive, can be developed. In considering a possibility to make effective use of melanoidin as a food constituent, it will be necessary to make a nutritional study on melanoidin.

Recently, G. C. Fahey et $a l^{3)}$ separated brown pigments from cane molasses and showed that a diet containing these brown pigments stimulated the growth of rats. Chichester et al.") reported that diets containing Maillard reaction products formed from a reaction mixture of reducing sugars and protein or amino acid caused diarrhea as well as depressed growth in rats. These varied responses of

' This work was presented at the Annual Meeting of the Japanese Society of Food and Nutrition on May 21, 1977 in Tokyo and on May 20, 1978 in Fukuoka. rats to browned products may be ascribed to chemical differences among the browned products fed to the rats. At present the chemical structure of melanoidin is still uncharacterized, and it is difficult to make an exact chemical comparison and identification of browned products prepared from natural resources and from model systems.

In this study nondialyzable melanoidin was prepared from a model system of glucose and ${ }^{15} \mathrm{~N}$-glycine, and diets containing the melanoidin were fed to rats. The quantity of excreted melanoidin was estimated by colorimetry of aqueous extract of feces and by ${ }^{15} \mathrm{~N}$ balance of the rats. The digestibilities of protein and lipid in rats were determined. Some chemical differences between the original melanoidin and the excreted one were also studied.

\section{MATERIALS AND METHODS}

Preparation of nondialyzable melanoidin. A solution of $2 \mathrm{M}$ glucose, $2 \mathrm{M}$ glycine and $0.2 \mathrm{M}$ sodium bicarbonate was refluxed on heating for $7 \mathrm{hr}$, and the brownish solution was dialyzed for 7 days in cellulose tubing against distilled water which was continuously 
changed. The nondialyzate was condensed in vacuo with a rotary evaporator followed by lyophilization. In order to estimate the recovery percentage of dietary melanoidin in the excretes, ${ }^{15} \mathrm{~N}$-melanoidin was prepared from ${ }^{15} \mathrm{~N}$-glycine and glucose. The resulting ${ }^{15} \mathrm{~N}$-melanoidin was found to contain 1.15 atom percent excess of ${ }^{15} \mathrm{~N}$ by mass spectrometry and $6.15 \mathrm{mg}$ nitrogen per gram by the Kjeldahl method.

Growth trial. Male, 50 to $60 \mathrm{~g}$, weanling albino rats of the Wistar strain were commercially obtained. Animals were singly housed in metabolic cages in airconditioned animal quarters, and feces and urine were separately collected. Diet and water were supplied ad libitum. Salt and vitamin mixtures were purchased from Tanabe Amino Acid Research Foundation. Oil was a mixture of one part of cod liver oil and four parts of soybean oil.

The first growth trial was carried out with diets of $10 \%$ protein level as presented in Table I where three groups, $2 \%, 0.1 \%$ and control are listed according to the level of the ${ }^{15} \mathrm{~N}$-melanoidin added to a diet. The number of rats per group was five. Changes in protein and melanoidin content of the diet were compensated for by corn starch content.

Table I. Composition of Control and Melanoidin Diet

\begin{tabular}{lccc}
\hline & \multicolumn{3}{c}{ Diet group } \\
\cline { 2 - 4 } \multicolumn{1}{c}{$\begin{array}{c}\text { Diet } \\
\text { constituent }\end{array}$} & Control & \multicolumn{2}{c}{ Melanoidin } \\
\cline { 2 - 4 } & & $2 \%$ & $0.1 \%$ \\
\hline${ }^{15}$ N-Melanoidin ${ }^{a}$ & - & 2.0 & $0.1 \%$ \\
Corn starch $_{\text {Casein }}$ & 75.85 & 73.85 & 75.75 \\
Oil mixture & 10.0 & 10.0 & 10.0 \\
Salt mixture & 8.0 & 8.0 & 8.0 \\
Vitamin mixture & 4.0 & 4.0 & 4.0 \\
Cellulose & 1.0 & 1.0 & 1.0 \\
Choline chloride & 1.0 & 1.0 & 1.0 \\
\end{tabular}

a The excess of ${ }^{16} \mathrm{~N}$ is 1.5 atom percent.

The second growth trial was carried out for 40 days with three groups in order to investigate the effect of melanoidin on the digestibilities of protein and lipid and on growth response. One group of 10 rats was fed with a control diet of $10 \%$ protein level. A second group was fed with a similar diet in which $2 \%$ of melanoidin had been incorporated, and a third group was fed with a diet containing $0.735 \%$ of glycine to bring the concentration of nitrogen to that of the $2 \%$ melanoidin diet.

The third growth trial was carried out for 32 days with three groups in order to estimate the recovery percentage of dietary melanoidin in the excretes and the digestibilities of protein and lipid. One group of 8 rats was fed with a control diet of $20 \%$ protein level. A second and a third identical groups were fed with similar diets in which $2 \%$ and $0.1 \%$ melanoidin had been incorporated, respectively.

Estimation of brown pigment recovered in excreta by colorimetry. Urine and feces were separately collected with a metabolic cage, and the brown pigment content of the excreta was determined. Two hundred milligrams of feces were extracted twice with 100 parts of pH 7 phosphate buffer $(0.1 \mathrm{M})$, followed by extraction with $0.01 \mathrm{~N}$ sodium hydroxide. The alkaline extract from feces was neutralized with dilute hydrochloric acid. The extracts were combined, and the quantity of brown pigment was estimated by multiplying the volume of the extracted solution by optical density in the visible range $(400 \sim 550 \mathrm{~nm})$.

Estimation of melanoidin excreted in feces and urine by ${ }^{15} \mathrm{~N}$-balance. ${ }^{15} \mathrm{~N}$-Melanoidin prepared from glucose and ${ }^{15} \mathrm{~N}$-glycine was incorporated into the control diet of $10 \%$ protein level in order to bring the melanoidin content to 2 and $0.1 \%$, respectively. The growth trial for ${ }^{15} \mathrm{~N}$-melanoidin was carried out with rats, each weighing $69 \mathrm{~g}$ on the average. The number of rats per group was five. After 10 days of feeding the control diet to rats, their body weights reached about $100 \mathrm{~g}$ each, and the ${ }^{15} \mathrm{~N}$-melanoidin diets were fed to the test groups for 6 days. Feces and urine were collected for 7 days, and the feces were desiccated in vacuo. The total nitrogen in the feces and urine was determined by the Kjeldahl method, and a steam distillate of the Kjeldahl digest was trapped with sulfuric acid, followed by mass spectrometric analyses on ${ }^{15} \mathrm{~N}$.

Estimation of digestibilities of protein and lipid. Digestibility of protein was estimated by determining the total nitrogen in feces and diets by the Kjeldahl method. The estimation of lipid digestibility was carried out as described elsewhere; $2 \mathrm{~g}$ of feces underwent saponification with an alcohol solution of potassium hydroxide, acidification with dilute hydrochloric acid and extraction with petroleum ether. An aliquot volume of petroleum ether solution was diluted with a mixed solvent of equivalent volumes of benzene and alcohol, and then titrated with an alcohol solution of $0.1 \mathrm{~N}$ potassium hydroxide. The fatty acid content is expressed in terms of the corresponding stearic acid.

Chemical characteristics of melanoidin. In order to detect a difference in chemical characteristics between the original melanoidin and the excreted one, the reducing values ${ }^{5)}$ of potassium ferricyanide by the original melanoidin and by the nondialyzable melanoidin extracted from feces were determined. The reducing values are given in equivalent milligrams of ascorbic acid per optical density of the above solutions estimated at $450 \mathrm{~nm}$. 
Fecal melanoidin solution prior to dialysis and the original melanoidin were diluted to show an equal optical density at $450 \mathrm{~nm}$ in $\mathrm{pH} 7$ phosphate buffer $(0.1 \mathrm{M})$, and aliquots of the solution were subjected to column chromatography on Sephadex G-25 and 100 successively with an eluate of $\mathrm{pH} 7$ phosphate buffer $(0.1 \mathrm{M})$.

The aqueous extract from feces of rats fed with diets containing $2 \%$ melanoidin was dialyzed in cellulose tubing against distilled water for 2 days. The quantity of nondialyzable brown pigment was colorimetrically estimated in the visible range.

\section{RESULTS AND DISCUSSION}

Determination of melanoidin excreted in feces and urine by ${ }^{15} \mathrm{~N}$-balance

The first growth trial was designed to determine the amount of melanoidin excreted in feces and urine according to the balance of ${ }^{15} \mathrm{~N}$ by melanoidin. ${ }^{15} \mathrm{~N}$-Melanoidin was incorporated into the control diet of $10 \%$ protein level in order to bring the melanoidin content to 2 and $0.1 \%$, respectively. The excess of ${ }^{25} \mathrm{~N}$ melanoidin was 1.15 atom percent. The melanoidin diets were fed to rats for 6 days, and their urine and feces were collected separately. Growth data of the rats fed with ${ }^{15} \mathrm{~N}$-melanoidin are presented in Table II. Values of final body weight, diet intake and urinary nitrogen were not significantly different between the control and the melanoidin groups. In contrast, the $2 \%$ melanoidin group showed a distinct increase in total nitrogen content of feces and a decrease in protein digestibility.

The feces and the urine of the melanoidin groups were analyzed to determine the atom percentage of excess ${ }^{15} \mathrm{~N}$, and the results are shown in Table III. (The results of analyses to determine the atom percentage of excess ${ }^{15} \mathrm{~N}$ in the $0.1 \%$ melanoidin group were omitted from the table because the values were almost the same as the percentage of natural nitrogen.) Seventy-six percent of ${ }^{15} \mathrm{~N}$ by melanoidin fed to rats was found to be excreted in the feces and $1.8 \%$ in the urine of the $2 \%$ melanoidin group. The atom percentage of excess ${ }^{15} \mathrm{~N}$ in the urine was too small to determine exactly. The authors suggest either of the following two possibilities for the amount of ${ }^{15} \mathrm{~N}$ not ac-

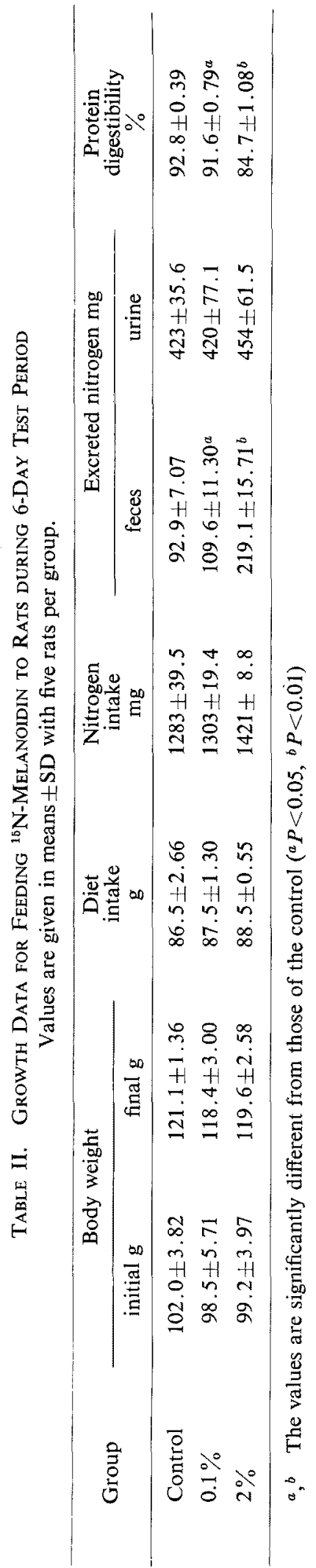


Table III. Recovery of Melanoidin In Feces AND URINE ESTIMATED BY ${ }^{15} \mathrm{~N}$-BALANCE on $2 \%$ Melanoidin Group

Values are given in means $\pm S D$ with five rats per group.

\begin{tabular}{lcc}
\hline & Feces & Urine \\
\hline $\begin{array}{l}\text { Nitrogen intake in } \\
\text { the form of melanoidin }\end{array}$ & $108.9 \pm 0.68 \mathrm{mg}$ \\
${ }^{15} \mathrm{~N}$ atom $\%$ excess & 1.15 \\
Total nitrogen & & \\
in excrete & $219 \pm 15.7 \mathrm{mg}$ & $454 \pm 61.7 \mathrm{mg}$ \\
${ }^{15} \mathrm{~N}$ atom \% excess & $0.44 \pm 0.022$ & $0.005 \pm 0.0031$ \\
Recovery of ${ }^{15} \mathrm{~N}$ & & \\
in excrete & $76.9 \pm 6.03$ & $1.8 \pm 0.76 \%$ \\
\hline
\end{tabular}

counted for in the urine and the feces: (a) the excreta were collected for one day after ceasing to feed ${ }^{15} \mathrm{~N}$-melanoidin to the rats, and less digestible substances such as melanoidin were accumulated in the caecum; (b) as stated in some reports, ${ }^{6)}{ }^{15} \mathrm{~N}$-melanoidin fed to rats was absorbed through the intestines probably after some chemical modification by microflora and enzymes in the intestines, and all the absorbed ${ }^{15} \mathrm{~N}$-compounds were not excreted.

It follows that the above-mentioned distinct decrease in protein digestibility was caused by the fecal nitrogen derived from melanoidin, and that the value corrected by subtracting melanoidin derived nitrogen from total nitrogen in diets and feces was $92 \%$.

\section{Estimation of brown pigments excreted in feces} by colorimetry

Although a brown pigment was occasionally observed in the urine of rats fed with diets containing melanoidin, the apparent color of their urine was not different from that of the controls when a metabolic cage was well controlled. It follows that melanoidin fed to rats was not excreted in their urine in the form of brown colorant. In order to determine the amounts of ${ }^{15} \mathrm{~N}$-melanoidin pigments excreted in feces, the feces of the control and test groups were extracted by the successive use of $\mathrm{pH} 7$ phosphate buffer and $0.01 \mathrm{~N}$ sodium hydroxide. The amounts of melanoidin pigment in feces are shown in Table IV. Since a small amount of pigment was detected in the feces of the control group, melanoidin excreted in feces was calculated by subtracting the quantity of basal pigment, 181, from that in the feces of each test rat. More than $62 \%$ of melanoidin fed to rats was colorimetrically found to be recovered in feces. In the feces of rats fed with $0.1 \%$ melanoidin diet, more than $66 \%$ of melanoidin was recovered. This could be attributed to alteration of melanoidin into less or noncolorant compounds through digestion in the intestines, as a result of which not all of the melanoidin fed to rats was recovered in the feces as colorimetrically determined. ${ }^{6,7\}}$

\section{Growth response of rats fed with dietary melanoidin}

The second growth trial was designed to investigate whether melanoidin in a diet of $10 \%$ protein level caused depression or stimulation of rat growth. As shown in Table V, there were no significant differences between the control and melanoidin groups in weight gain, diet consumption, diet efficiency or liver weight. As shown in Table VI, protein digestibility was distinctly lowered in the group fed with a diet containing $2 \%$ melanoidin, whereas the three groups did not significantly differ in lipid digestibility. The $2 \%$ melanoidin group showed the same levels of weight gain and lower protein digestibility as the control, implying inconsistent results. As de-

Table IV. Recovery of Dietary Melanoidin in Feces Estimated

BY COLORIMETrRY AT $450 \mathrm{~nm}$

Value are given in means \pm SD with five rats per group.

\begin{tabular}{lcccc}
\hline Dietary group & $\begin{array}{c}\text { Total pigment } \\
\text { in feces }\end{array}$ & $\begin{array}{c}\text { Melanoidin } \\
\text { in feces }\end{array}$ & $\begin{array}{c}\text { Dietary } \\
\text { melanoidin }\end{array}$ & $\begin{array}{c}\text { Recovery } \\
(\%)\end{array}$ \\
\hline Control & $181 \pm 81.2$ & - & - & - \\
$0.1 \%$ Melanoidin & $584 \pm 90.0$ & $392 \pm 72.7$ & $590 \pm 9.0$ & $66.2 \pm 11.65$ \\
$2 \%$ Melanoidin & $7790 \pm 197.0$ & $7514 \pm 194.0$ & $11953 \pm 74.1$ & $62.8 \pm 1.26$ \\
\hline
\end{tabular}




\section{Table V. Growth Response of Rat Fed with a Diet Containing Melanoidin at the Level of $10 \%$ Protein}

Values are given in means $\pm \mathrm{SD}$, and are not significantly different between the test group and the control $(P<0.05)$.

\begin{tabular}{|c|c|c|c|c|c|c|}
\hline \multirow{2}{*}{ Dietary group. } & \multicolumn{2}{|c|}{ Body weight, $g$} & \multirow{2}{*}{$\begin{array}{l}\text { Body weight } \\
\text { gain per day }\end{array}$} & \multirow{2}{*}{$\begin{array}{c}\text { Diet } \\
\text { consumption, } \\
\mathrm{g}\end{array}$} & \multirow{2}{*}{$\begin{array}{c}\text { Diet }^{a} \\
\text { efficiency }\end{array}$} & \multirow{2}{*}{$\begin{array}{l}\text { Liver weight } \\
\text { per } 100 \mathrm{~g} \\
\text { body weight }\end{array}$} \\
\hline & initial & final & & & & \\
\hline Control. & $83.2 \pm 6.78$ & $203.1 \pm 9.40$ & $3.00 \pm 0.143$ & $560.1 \pm 20.63$ & $0.214 \pm 0.0072$ & $3.44 \pm 0.334$ \\
\hline Glycine & $85.6 \pm 2.15$ & $201.2 \pm 10.62$ & $2.90 \pm 0.254$ & $552.6 \pm 41.83$ & $0.210 \pm 0.0117$ & $3.58 \pm 0.321$ \\
\hline $2 \%$ Melanoidin & $82.5 \pm 5.32$ & $202.0 \pm 9.63$ & $2.94 \pm 0.216$ & $546.3 \pm 47.28$ & $0.216 \pm 0.0086$ & $3.65 \pm 0.313$ \\
\hline
\end{tabular}

a Diet efficiencies are given in body weight gains per gram of diet consumed.

Table VI. Effect of Feeding Melanoidin to Rats on the Digestibility of Protein AND LIPID

The determination of digestibility was carried out from the 32 th to 40 th day of the test period, and the average body weight of the rats on the $32 \mathrm{th}$ day was $177.5 \mathrm{~g}$. The values are given in means $\pm S D$.

\begin{tabular}{lccccc}
\hline Dietary group & $\begin{array}{c}\text { Diet } \\
\text { consumption } \\
\text { g }\end{array}$ & $\begin{array}{c}\text { Urinary } \\
\text { nitrogen } \\
\mathrm{mg}\end{array}$ & $\begin{array}{c}\text { Fecal } \\
\text { nitrogen } \\
\mathrm{mg}\end{array}$ & \multicolumn{2}{c}{ Digestibility (\%) } \\
\hline Control & $120 \pm 6.7$ & $443 \pm 102.6$ & $110 \pm 16.0$ & $93.8 \pm 0.75$ & $96.4 \pm 1.26$ \\
Glycine & $117 \pm 8.3$ & $457 \pm 94.8$ & $108 \pm 13.8$ & $94.3 \pm 0.67$ & $95.5 \pm 1.14$ \\
$2 \%$ Melanoidin & $120 \pm 4.1$ & $485 \pm 83.5$ & $218 \pm 12.3^{a}$ & $88.7 \pm 0.83^{a}$ & $96.5 \pm 1.30$ \\
\hline
\end{tabular}

a The values are significantly different from those of the control $(P<0.01)$.

Table VII. Growth Response and Proetin Digestibility of Rats Fed with a Diet Containing Melanoidin at the Level of $20 \%$ Protein

Values are given in means $\pm S D$ with eight rats per group.

\begin{tabular}{lcccccc}
\hline $\begin{array}{c}\text { Dietary } \\
\text { group }\end{array}$ & $\begin{array}{c}\text { Final body } \\
\text { weight, }\end{array}$ & $\begin{array}{c}\text { Weight } \\
\text { gain, }\end{array}$ & $\begin{array}{c}\text { Diet } \\
\text { consumption,g }\end{array}$ & $\begin{array}{c}\text { Diet } \\
\text { efficiency }\end{array}$ & $\begin{array}{c}\text { Lever weight per } \\
\text { 100g body weight }\end{array}$ & $\begin{array}{c}\text { Protein } \\
\text { digestibility }\end{array}$ \\
\hline $\begin{array}{l}\text { Control } \\
0.1 \%\end{array}$ & $275.1 \pm 4.71$ & $203.4 \pm 4.84$ & $483.7 \pm 10.08$ & $0.421 \pm 0.0126$ & $4.51 \pm 0.402$ & $96.2 \pm 0.94$ \\
$\begin{array}{l}\text { Melanoidin } \\
2 \%\end{array}$ & $275.4 \pm 10.02$ & $203.0 \pm 10.51$ & $490.0 \pm 11.18$ & $0.414 \pm 0.0222$ & $4.02 \pm 0.390$ & $96.1 \pm 0.57$ \\
Melanoidin & $278.8 \pm 9.98$ & $202.6 \pm 8.37$ & $499.8 \pm 7.00$ & $0.405 \pm 0.0143$ & $4.16 \pm 0.391$ & $92.1 \pm 0.77^{a}$ \\
\hline$a$
\end{tabular}

scribed in the experiment for the estimation of excreted ${ }^{15} \mathrm{~N}$ of melanoidin, $76 \%$ of nitrogen in dietary melanoidin was excreted in the feces; digestibility was more precisely estimated by subtracting melanoidin derived nitrogen from total nitrogen in the feces and diet. It follows that the protein digestibility of the $2 \%$ melanoidin group reached $93.5 \%$, implying that the addition of nondialyzable melanoidin to a diet of $10 \%$ protein level had no effect on protein digestibility.

The third growth trial was designed to determine growth response and protein digestibility of rats fed with dietary melanoidin at the level of $20 \%$ protein: As shown in Table VII, protein digestibility was also remarkably lower- ed in the $2 \%$ melanoidin group. In the second growth trial, the weight gain and diet efficiency of the melanoidin group were not significantly different from those of the control. In the feces of rats fed with $2 \%$ melanoidin diets of $20 \%$ protein level, $65 \%$ of melanoidin was colorimetrically found to be recovered. The excretion percentage of dietary melanoidin in the feces was almost equal to that of the first growth trial, and it would be reasonable to correct the amount of total nitrogen in the feces according to the above excretion percentage of ${ }^{15} \mathrm{~N}$ in feces. Consequently, the increase in total fecal nitrogen was attributable to the nitrogen derived from melanoidin. For this reason, the protein digestibility of the $2 \%$ 
melanoidin group was corrected to $96 \%$, about equal to that of the control. It follows that nondialyzable melanoidin in a diet has no effect on growth response or the digestibility of protein and lipid.

Comparison of chemical characteristics between the original melanoidin and the excreted melanoidin

Melanoidin extracted from feces of rats fed with $2 \%$ melanoidin diets underwent dialysis, and the quantity of pigment in cellulose tubing was colorimetrically estimated at $450 \mathrm{~nm}$ before and after the dialysis. The proportion of nondialyzable melanoidin of feces exceeded $98 \%$. Equal quantities of the original melanoidin and the excreted one, estimated by optical density at $450 \mathrm{~nm}$, were applied on the columns of Sephadex G-25 and 100. Since no dialyzable melanoidin in the feces was present, the original melanoidin and excreted one were detected as only a negligible component in the low mole-

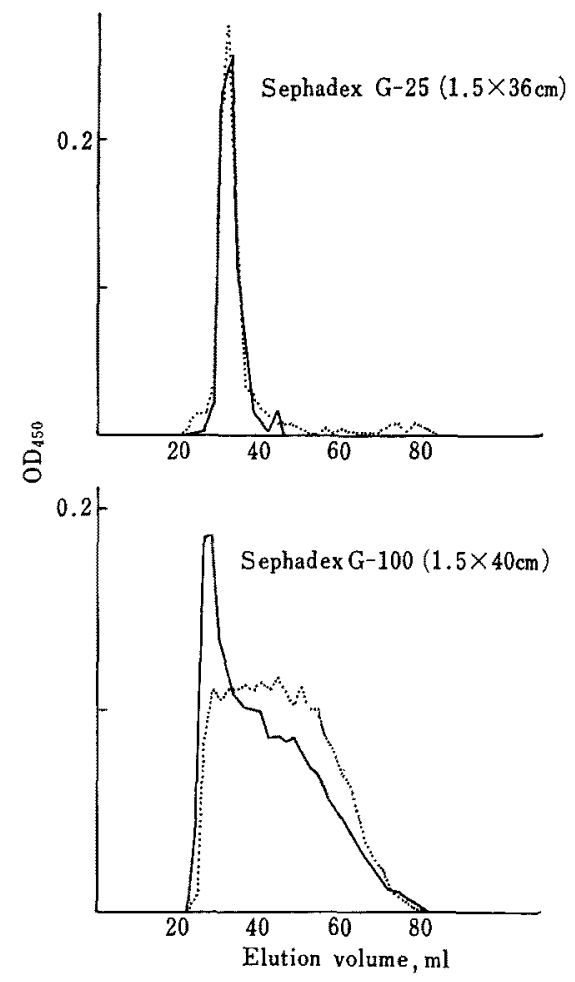

FIg. 1. Gel Filtration Chromatography of Melanoidin on Sephadex.

-_, feces; ------, original. cular fraction by gel filtration chromatography on Sephadex G-25 (Fig. 1). In the feces of rats fed with dietary melanoidin no dialyzable brown pigment remained even when melanoidin fed to rats was degraded into low molecular pigment during the digestive process.

Compared by chromatographic pattern on Sephadex G-100 (Fig. 1), the melanoidin excreted in feces had a smaller proportion of low-molecular components. In estimating the excretion percentage of melanoidin in the feces, the colorimetric method gave a lower value than the ${ }^{15} \mathrm{~N}$-balance method. Therefore, the dietary melanoidin was altered into less or noncolorant materials during the digestive process, and part of it might be absorbed by the intestines. It seems that intestinal microflora and enzymes ${ }^{\hat{\theta}, 7)}$ had a metabolic activity on low-molecular melanoidin and that highmolecular components of melanoidin were relatively resistant to this alteration and remained in the feces. Isolation and identification of these less or non-colorant materials in the future may lead to chemical elucidation of melanoidin.

Reducing values of the original melanoidin and excreted one were shown to be respectively 3.00 and $2.30 \mathrm{mg}$ in ascorbic acid equivalents per optical density estimated at $450 \mathrm{~nm}$. The decrease in reducing value of melanoidin excreted in the feces may be attributed to the oxidation of reducing groups such as endiol or enaminol. ${ }^{13}$ For details of the chemical structure and change of melanoidin, it is necessary to estimate more exactly the active groups in the molecules. ${ }^{8)}$

The authors have made an analysis of the components of the original melanoidin and the excreted one by electrophoresis, which was found to be a useful method for separation of melanoidin. The results will be presented in a succeeding report.

During the keeping of the rats for two months, no unusual behaviour was observed in the rats fed with melanoidin diets. After the rats were sacrificed, the digestive organs were pathologically examined, and no difference was observed between the control and the mela- 
noidin group. Therefore, nondialyzable melanoidin had no effect on the growth response of rats.

Acknowledgement. Thanks are due to Misses Kazuko Tanaka, Naomi Tsuchisaka and Noriko Sogabe of the Department of Food and Nutrition, Ochanomizu University for their engagement in the experimental work.

\section{REFERENCES}

1) N. Kirigaya, H. Kato and M. Fujimaki, Agric. Biol. Chem., 32, 287 (1968); idem, Nippon Nôgeikagaku Kaishi, 43, 484 (1968); idem, ibid., 45, 292 (1971).

2) N. Yamaguchi, Y. Yokoo and Y. Koyama, $J$. Jpn. Soc. Food Sci. Technol., 11, 184 (1964); N. Yamaguchi and Y. Koyama, ibid., 14, 106, 110, 281 (1967).
3) G. C. Fahey, J. E. Williams and G. A. McLaren, J. Nutr., 106, 1447 (1976).

4) C. M. Lee, C. O. Chichester, and T-C. Lee, "Physiological Consequences of Browned Food Products," Proc. Int. Cong. Food Sci. Technol., 4th, 1977.

5) T. Adachi, Nippon Nôgeikagaku Kaishi, 32, 313 (1958).

6) M. C. Nesheim and K. J. Carpenter, Brit. J. Nutr., 21, 399 (1966); J. Valle-Riestra and R. H. Barnes, J. Nutr, 100, 873 (1970).

7) V. C. Sgarbieri, J. Amaya, M. Tanaka and C. 0. Chichester, ibid., 103, 657 (1973); M. Tanaka, T. C. Lee and C. O. Chichester, ibid., 105, 989 (1975).

8) H. Kato, G. Noguchi and M. Fujimaki, Agric. Biol. Chem., 32, 916 (1968); H. Kato, T. Gomyo and M. Fujimaki, Nippon Nôgeikagaku Kaishi, 45, 559 (1971). 